Institutionen för språk och litteraturer

Box 200, 40530 Göteborgs universitet

Département de langues et de littératures,

Université de Göteborg, Suède
Université Paris IV

École doctorale IV

28 , rue Serpente

75006 Paris

\title{
Fantastique et révolte chez Jean Muno et Hugo Raes
}

Åsa Josefson

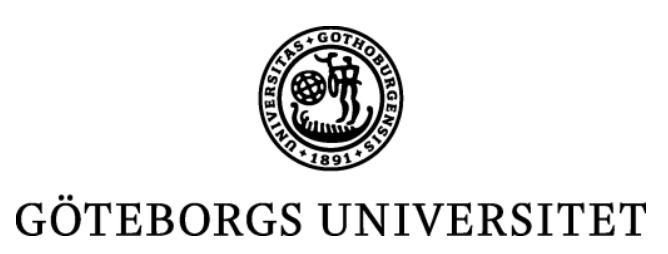

Institutionen för språk och litteraturer

F R A N K A

Thèse pour le doctorat présentée et publiquement soutenue le 6 mars 2010 à $14 \mathrm{~h}$, salle D040, Maison de la recherche, 28 rue Serpente, 75006 Paris. 


\section{FANTASTIQUE ET REVOLTE CHEZ JEAN MUNO ET HUGO RAES}

This thesis examines the thematic of revolt in the work of two Belgian writers, Jean Muno (1924-1988), French-speaking, and Hugo Raes (1929-), Dutch-speaking. It is not a comparative study of their texts; the differences between them exclude such an approach. The present study highlights a thematic that connects two authors from the same country, of the same generation, both active in the field of fantastic literature. It has a double aim: the analysis of the different components of the thematic of revolt in their work is the first. The second is to define the distinctive features of their fantastic texts with the aid of a model elaborated in the theoretic section of the thesis, inspired by Eleanor Rosch's prototype theory. The theory of the fantastic being rather complex through its diversity, the chosen solution is to facilitate the theoretic classification of the texts included in the corpus by applying the prototype theory to the fantastic. The most important advantage of the theory in question is that it allows more flexibility in the approach of the definition of the fantastic.

In studies on Belgian literature, the perspective tends to be mostly unilingual, the focus being either on French-speaking literature, or on its Flemish equivalent. The present work combines them both in order to show that there is a common tradition of the fantastic in Belgium, whose origins are probably to be found in the pictorial art of the Middle Ages. This thesis is also the first monograph on both Muno and Raes.

In Muno's novels and short stories, the existential revolt of the protagonist proves to be central, whereas the revolt in Raes's writings is directed against society, taking the form of a sharp social criticism. The main characters in Muno's work generally suffer from the authoritarian attitude of those around them, who represent conventional and conformist values. The fantastic offers a possibility either to escape or to revolt against this kind of oppression. In Raes's work, the fantastic or science-fictional element has another function, namely to reinforce the warning conveyed by the text. Most of his characters are in opposition to a society that is represented as destructive. The protagonists in Muno's and Raes's texts do not fight the same adversary, but they share the spirit of rebellion.

\section{Key words}

Jean Muno, Hugo Raes, littérature belge, fantastique, surnaturel, merveilleux, réalisme magique, théorie des prototypes, Eleanor Rosch, révolte existentielle, critique sociale, enseignement, conventions, conformisme, utopie, anarchisme. 